\title{
Education regarding relationship of nutritional status to short stature and level of intelligence to parents of elementary school students
}

\author{
Lili Rohmawati ${ }^{1 *}$, Winra Pratita ${ }^{1}$, Ika Citra Dewi Tanjung ${ }^{2}$, Nindia Sugih Arto ${ }^{3}$ \\ ${ }^{1}$ Departement of Paediatric Medical Faculty of Universitas Sumatera Utara \\ ${ }^{2}$ Departement of Biochemistry Medical Faculty of Universitas Sumatera Utara \\ ${ }^{3}$ Departement of Clinical Pathology Medical Faculty of Universitas Sumatera Utara \\ *Email: lily_rahmawati234@yahoo.com
}

\begin{abstract}
Short stature is a health problem with long-term implications to the future of the children. Short stature condition in children below five years old, known as stunting, may cause cognitive, psychomotor impairment and interfere with productivity on adult period. Main concern in short stature is due to insufficient of dietary intake in long-term period. Parents' role in the prevention of short stature is important, therefore, performing education to parents is a crucial task to the government, universities and communities to be done continuously. The objective of this educational counseling was to educate the parents so they would be able to comprehend the relationship of nutritional status to short stature, especially in children below five years old, and level of intelligence in order to prevent the condition of short stature in the future. This activity was held in conjunction with community service program Pengabdian Kepada Masyarakat Dosen Wajib Mengabdi Universitas Sumatera Utara (USU) 2019, by the lecturer team of Faculty of Medicine USU in elementary school Yayasan Pendidikan Al-Washliyah Tanjung Rejo, Medan. Educational counseling materials were modules and leaflets distributed to the parents. To evaluate the educational counseling, questionnaires were disposed prior to and after the lecture. The target audience was the parents of elementary school students, amount of 48 people. The results showed mean difference questionnaires' score of 0.97 (SD 1.76) with $95 \% \mathrm{CI}=0.46-1.49$ and $\mathrm{p}$ value $=0.001(\mathrm{p}<0.05)$. There was significant difference of parental knowledge to educational counseling material prior to and after the counseling. Concluded, parental knowledge regarding relationship of nutritional status to short stature and level of intelligence is significantly increased through the educational counseling.
\end{abstract}

Keyword: Educational counseling, nutritional status, short stature, level of intelligence

\section{INTRODUCTION}

Short stature is a serious health problem as it is associated with long-term implications to the future of the children. Short stature in children below five years old mainly due to inadequate nutritional intake, termed as stunting, may cause cognitive and psychomotor impairment that lead to decrease productivity on adult period. Chronic infections may occur in children with short stature that may cause school absences. Main cause of short stature is known as long-term insufficient nutritional intake (Victora et al, 2008; WHO, 2018; UNICEF, 2018; KEMENKES, 2018a).

Based on the national survey, Riset Kesehatan Dasar (Riskesdas) 2018, prevalence of short stature in Indonesia is 30,8\% (KEMENKES, 2018b). In North Sumatera, based on surveillance Pemantauan Status Gizi (PSG) 2017, prevalence of short stature children below five years old is $28,43 \%$ (Dinkesprovsu, 2017). Study by Nasution, et al (2019) in Namorambe, Deliserdang, North Sumatera reported low maternal knowledge and attitude toward children with stunting (50,7\% and $55,8 \%$, respectively) (Nasution, 2019). Prevention of short stature in children is crucial as it is associated with level of intelligence and productivity on adult period, especially as the future's nation generation.

Parents' role in the prevention of short stature is important, therefore, performing education to parents is a crucial task to the government, universities and communities to be done continuously (KEMENKES, 2018). One of effective educational tool is educational counseling and 
two-way discussion to the parents with practical advices during the educational counseling (WHO, 2014).

The objective of this educational counseling was to educate the parents so they wolud be able to comprehend the relationship of nutritional status to short stature and level of intelligence in order to prevent the condition of short stature in the future.

\section{METHODS}

This activity was held in conjunction with community service program "Dosen Wajib Mengabdi Universitas Sumatera Utara (USU) 2019", by the team from Faculty of Medicine USU, composed of five lecturers and five medical students. Place was in elementary school Yayasan Pendidikan Al-Washliyah Tanjung Rejo Medan, on August 15, 2019 in conjunction with National Independence Day celebration on the school. The prevalence of children with short stature in the school was $30 \%$.

The target for educational counseling was parents of elementary school students. Educational counseling was performed with the topic relationship of nutritional status to short stature and level of intelligence of the children. The educational counseling content was composed of the following: (a) the etiology of children with short stature, (b) nutrition for optimal growth and development, (c) the importance of environmental hygiene and hand hygiene, (d) prevention of anemia due to insufficient nutritional intake and its impact to level of intelligence, and (e) stimulation to improve children's intelligence. Respective topics were delivered by competence lecturers. Educational counseling utilized audio-visual and LCD as educational tools. Counseling materials were modules and leaflets distributed to the parents. In order to evaluate the parental knowledge progress, questionnaires were distributed to the parents prior to and after the educational counseling. Data was statistically analyzed with dependent t-test and $\mathrm{p}$ value of $<0.05$ was considered significant.

This activity was supported by the school principal and teachers, they provided assistance to the educational counseling team and parents during the educational counseling process.

\section{RESULT AND DISCUSSION}

This activity was part of the obligatory Tridarma university to the lecturers. Funding was supported by Universitas Sumatera Utara in Program Pengabdian Kepada Masyarakat Dosen Wajib Mengabdi tahun 2019 (lecturer to community service program). This activity was aimed in assisting lecturer in community service as part of tangible act in providing specific knowledge to the community.

Activity was held on Wednesday, August 15, 2019 with 48 parents of elementary school students as participants. Total amount of students in elementary school of Yayasan Pendidikan AlWashliyah, Tanjung Rejo, Medan was 156 students. Initial target of 100 parents was not accomplished due to activity was held during work-hour, therefore many parents missed the opportunity to attend the program. Most of the parents had low-social economy level, hence both parents were working. Attending parents had middle class income and one parent was jobless. Subjects were mostly housewives. Mean parental age was 38,1 years old. Characteristics of educational counseling subjects were described in Table 1.

Table 1. Characteristics of educational counseling subjects 


\begin{tabular}{ll}
\hline Characteristics & $\mathrm{N}=48$ \\
\hline Age (Year) & $25-51$ \\
Range & $38,1(6,0)$ \\
Mean (SD) & $15(31,3)$ \\
Sex & $33(68,8)$ \\
$\quad$ Man, $\mathrm{n}(\%)$ & $10(20,8)$ \\
Woman, $\mathrm{n}(\%)$ & $6(12,5)$ \\
Education & $22(45,8)$ \\
Elementary school, $\mathrm{n}(\%)$ & $10(20,8)$ \\
Junior high school, $\mathrm{n}(\%)$ & $30(62,5)$ \\
Senior high school, $\mathrm{n}(\%)$ & $7(14,6)$ \\
Bachelor, $\mathrm{n}(\%)$ & $11(22,9)$ \\
Occupation & \\
Housewife, $\mathrm{n}(\%)$ & 0 \\
Employee, $\mathrm{n}(\%)$ & $48(100)$ \\
Merchandiser, $\mathrm{n}(\%)$ & $8(16,7)$ \\
Family income (Rp) & \\
<2,5 million, $\mathrm{n}(\%)$ & $40(83,3)$ \\
2,5- 5 million, $\mathrm{n}(\%)$ & $6-30$ \\
Number of children (person) & \\
$<2, \mathrm{n}(\%)$ & $13,5(5,9)$ \\
$\geq 2, \mathrm{n}(\%)$ & $1-14$ \\
Age of the first child (year) & $6,5(2,6)$ \\
Range & \\
Mean (SD) & \\
Age of the last child (year) & \\
Range & \\
Mean (SD) & \\
&
\end{tabular}

During educational counseling, the parents gave full attention and asked questions regarding nutritional practice in order to prevent short stature and parenting strategies to achieve optimal level of intelligence. Study in Kupang and East Timur to stunting children revealed that the more severe stunting condition, the academic status of the children would be lower (Picauly \& Toy, 2013).

Table 2 showed mean difference of parental knowledge regarding education materials prior to and after the educational lecture. There was difference of questionnaires score of $0,97(\mathrm{SD} \pm 1,76)$ with $95 \% \mathrm{CI} \quad(0,46-1,49)$ and $\mathrm{p}=0,001$. It was shown that there was significant difference of score prior to and after the educational counseling.

Table 2. Differences of questionnaires score of parental knowledge prior to and after the educational counseling

$\begin{array}{lcc}\begin{array}{l}\text { Educational } \\ \text { lecture }\end{array} & \text { Mean score (SD) } & P \\ \text { Prior to } & 7,77(2,85) & \\ \text { After Difference } & 8,75(2,85) & 0,001\end{array}$

There are many risk factors known for short stature. Lack of nutritional knowledge may predispose to insufficient quality of family food that may lead to stunting. Study in Surabaya 
showed that the proportion of mothers with lower nutritional knowledge was larger in stunting children group compared to those with non-stunting children group $(61,8 \%$ and $29,4 \%$, respectively) (Ni'mah dan Nadhiroh, 2015). Study in east Semarang also showed that parental knowledge was a risk factor of stunting in children below five years old (Nasikhah dan Margawati, 2012). Other study also revealed that parental lack of knowledge had 3,27 times increase risk of stunting compared to those with sufficient knowledge (Kusumawati dkk, 2015). Study in Klaten reported that the most significant risk factor of stunting was variety of food (Widyaningsih dkk, 2018). Study in Jember showed that risk factors associated with stunting in urban and rural areas were maternal education, family income, maternal knowledge of nutrition, exclusive breastfeeding, age of complimentary food initiation, sufficiency of zinc and iron, history of chronic infections and genetic factors (Aridiyah dkk, 2015).

Parental education regarding adequate family nutrient intake is important in order to ensure sufficient nutritional knowledge. Integrated parental education regarding nutritional status to short stature and level of intelligence is very important (Aryastami dan Tarigan, 2017). Wuryanti et al performed nutrition educational counseling in Kemayoran,Central Jakarta, reported that maternal knowledge significantly increased after the counseling (Wuryanti dkk, 2019). Several studies also showed the increment of parental knowledge after educational counseling was performed audio-visually and active question-answer sessions (Hati \& Pratiwi, 2019). This activity is held in the form of educational counseling and leaflet distribution. In accordance to previous studies, combination methods by educational counseling utilizing audio-visual tools and leaflet distribution were more effective than single method. It was reported from previous nutrition counseling, there was increment in parental nutritional knowledge (Dewi \& Aminah, 2016). Study in Nigeria reported that educational counseling regarding nutrition and health to maternal population may increase their knowledge (Fadare et al, 2019).

This activity was performed in elementary school with most of the students' family came from middle to low socio-economic level. Attended parents had middle socio-economic level with monthly income of 2,5 to 5 million IDR. Parents from low socio-economic level could not attend the educational counseling as most of them were at work. The family income also a risk factor associated with stunting in children (Aridiyah dkk, 2015). Study in Padang showed significant relationship between family income and the occurrence of stunting in children age of 24-59 months old, asides from maternaleducation level which was had strong relationship (Setiawan dkk, 2018).

Mean parental education level on this activity predominantly was senior high school. Previous studies showed that low parental education level was a risk factor for stunting (Ni'mah dan Nadhiroh, 2015; Aridiyah dkk, 2015; Setiawan dkk, 2018). Study in Nairobi reported that maternal education level was a strong predictor of stunting (Abuya et al, 2012). Family empowerment is one of strategic effort to prevent stunting (Moestue \& Huttly, 2018; Kusumawati, 2015).

This educational counseling was composed of hygiene and sanitation, how to perform hand hygiene and promote self- hygiene. Educator showed the act of hand hygiene followed by parents and students. Study in Indonesia by Torlesse et al showed that the prevalence of stunting was lower in community with improvement in drinking water source, hygiene and sanitation compared to those without improvement (Torlesse et al, 2016). 


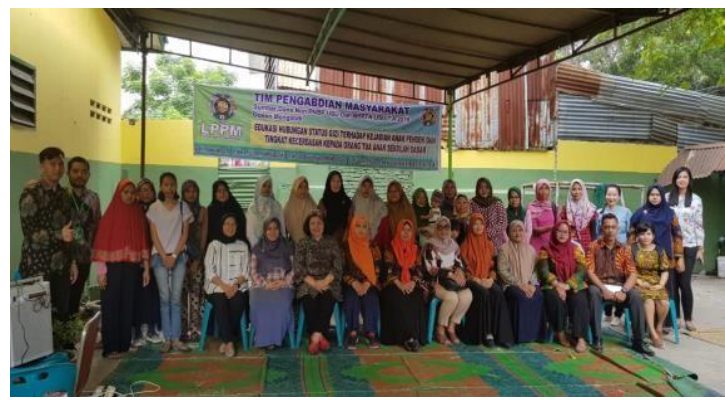

Figure 1. Educational counseling team, teachers and parents of elementary school students, AlWashliyah, Tanjung Rejo, Medan

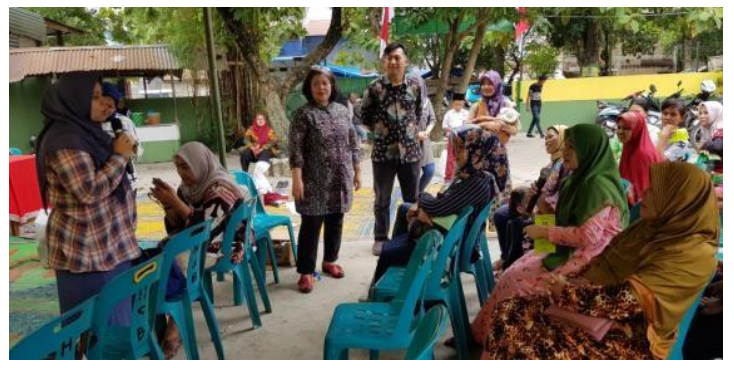

Figure 2. Educational counseling activity and Q \& A sessions

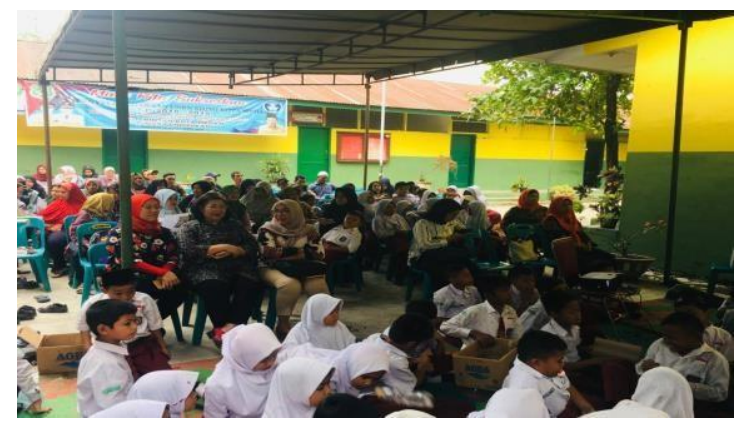

Figure 3. Parents as participants of educational counseling

\section{CONCLUSION}

Community service program for the lecturers of Universitas Sumatera Utara plays an important role in assisting the lecturer in providing educational counseling to local community regarding children with short stature, etiology and its implication to level of intelligence.

Parental knowledge is significantly increase through educational counseling regarding relationship of nutritional status to short stature and level of intelligence.

\section{ACKNOWLEDGMENTS}

We would like to express our gratitude to Universitas Sumatera Utara for funding this activity through Program Pengabdian Kepada Masyarakat of Year 2019 with Contract Number 815/UN5.2.3.2.1/PPM/2019.

\section{REFERENCES}


Abuya, B.A., Onsomu, E.O., Kimani, J.K., Moore D. Influence of Maternal Education on Child Immunization and Stunting in Kenya. Matern Child Health J .15:1389-99.

Aridiyah, F.O., Rohmawati, N., Ririanty, M. 2015. The Factors Affecting Stunting on Toddlers in Rural and Urban Areas. e-Jurnal Pustaka Kesehatan. 3 (1); 163-70.

Aryastami, N.K., Tarigan, I. 2017. Kajian kebijakan dan penanggulangan masalah gizi stunting di Indonesia. Buletin Penelitian Kesehatan. 45(4): 233 - 240.

Cameron, L., Shah, M., Olivia, S. 2013. Impact evaluation of a large-scale rural sanitation project in Indonesia, Water and Sanitation Program. Impact Evaluation Series No. 83, Policy Research Working Paper WPS6360. Washington: World Bank.

Dewi, M., Aminah, M. 2016. The Effect of Nutritional Knowledge on Feeding Practice of Mothers Having Stunting Toddler Aged 6-24 Months. Indonesian Journal of Human Nutrition. 3 (1): 1 -8 .

[Dinkesprovsu] Dinas Kesehatan Provinsi Sumatera Utara, Bidang Kesehatan Masyarakat. 2018. Gambaran status gizi masyarakat, balita kurang energi protein berdasarkan pemantauan status gizi. Accessed on Desember 2, 2018. Available at http://dinkes.sumutprov.go.id/v2/berit a-309-gambaran status-gizimasyarakat-balita-urangenergi-protein-berdasarkan pemantauan-status-gizi.html.

Fadare, O., Amare, M., Mavrotas, G., Akerele, D., Ogunniyi, A. 2019. Mother's nutrition-related knowledge and child nutrition outcomes: Empirical evidence from Nigeria. PLoS ONE. 14(2): e0212775.

Hati, F.C., Pratiwi, A.M. 2019. The effect of education giving on the parent's behavior about growth stimulation in children with stunting. Nurse Line Journal. 4 (1): 12-20.

[Kemenkes RI] Kementerian Kesehatan Republik Indonesia. 2018a. Situasi balita pendek (stunting) di Indonesia. In: Buletin Jendela Data dan Informasi Kesehatan, Semester I. Pusat Data dan Informasi (Pusdatin) Kementerian Kesehatan RI, Jakarta.

[Kemenkes RI] Kementerian Kesehatan Republik Indonesia. 2018b. Riset kesehatan dasar (Riskesdas) 2018. Badan Penelitian dan Pengembangan Kesehatan Republik Indonesia, Jakarta.

Kusumawati, E., Rahardjo, S., Sari, H.P. 2015. Model pengendalian faktor risiko stunting pada anak usia di bawah tiga tahun. J Kesehat Masy Nas. 9(3): 249-256.

Moestue H, Huttly S. Adult education and child nutrition: the role of family and community. $\mathbf{J}$ Epidemiol Commun. 62:153-9.

Nasikhah, R., Margawati, A. 2012. Faktor risiko kejadian stunting pada balita usia 24-36 bulan di Kecamatan Semarang Timur. Journal of Nutrition College,1(1): 176-84.

Nasution, S.S., Oktavinola, F., Hariati. 2019. Mother's knowledge and attitude about stunting of children in namorambe distric. ABDIMAS TALENTA. 4 (1): 61-65.

Ni'mah, K., Nadhiroh, S.R. 2015. Faktor yang berhubungan dengan kejadian stunting pada balita. Media Gizi Indonesia. 10 (1): 13-19. 
Picauly, I.,Toy, S.M. 2013. Analisis determinan dan pengaruh stunting terhadap prestasi belajar anak sekolah di kupang dan sumba timur, NTT. Jurnal Gizi dan Pangan. 8(1), hal. 55-62.

Setiawan, E., Machmud, R., Masrul. 2018.Faktor-faktor yang berhubungan dengan kejadian stunting pada anak usia 24-59 bulan di wilayah kerja puskesmas andalas kecamatan padang timur kota padang tahun 2018. Jurnal Kesehatan Andalas. 7(2): 275-84.

Torlesse, H., Cronin, A.A., Sebayang, S. K., Nandy, R. (2016). Determinants of stunting in Indonesian children: Evidence from a cross-sectional survey indicate a prominent role for the water, sanitation and hygiene sector in stunting reduction. BMC PublicHealth, 16, 669. https://doi.org/ 10.1186/s12889-016-3339-8.

[UNICEF] United Nation Children's Fund. 2018. Levels and trends in child malnutrition. WHO, Geneva.

Victora, C.G., Adair, L., Fall, C., Hallal, P.C., Martorell, R., Richter, L., et al. 2008. Maternal and Child Undernutrition Group Maternal and child undernutrition: consequences for adult health and human capital. Lancet. 371:340-357.

[WHO] World Health Organization. 2014. Comprehensive implementation plan on maternal, infant, and young child nutrition. WHO, Geneva.

[WHO] World Health Organization. 2018. Reducing stunting in children: equity considerations for achieving the global nutrition targets 2025. WHO, Geneva.

Widyaningsih, N.N., Kusnandar, Anantanyu,S. 2018. Keragaman pangan, pola asuh makan dan kejadian stunting pada balita usia 24-59 bulan. Jurnal Gizi Indonesia (The Indonesian Journal of Nutrition). 7(1):22-29.

Wuryanti, S., Marsiati, H., Andayani, S.H. 2019. Edukasi gizi seimbang anak usia 0-2 tahun pada ibu-ibu di kelurahan Harapan Mulia, Kemayoran/ Jakarta Pusat. ABDIMAS TALENTA 4(1): 9-12. 